\title{
FILOZOFICZNE PODSTAWY SPOLECZNEJ POLITYKI DLA ZRÓWNOWAŻONEGO ROZWOJU
}

We współczesnej ekonomii politycznej wypracowano doktrynę zrównoważonego rozwoju. Zakres przedmiotowy tej doktryny obejmuje środowisko, ekonomię i społeczeństwo. W publikacjach dotyczących zrównoważonego rozwoju więcej uwagi poświęca się środowisku i ekonomii, natomiast kwestia polityki społecznej schodzi w nim na dalszy plan. Autor artykułu, inspirując się myślą francuskiego neotomisty Etienne Gilsona staje na stanowisku, że doktryny zrównoważonego rozwoju nie można zawężać tylko do kwestii polityki gospodarczej. Skoro człowiek jest podmiotem i adresatem zrównoważonego rozwoju, to priorytetową kwestią $\mathrm{w}$ tej doktrynie powinna być społeczna polityka państwa. Ta natomiast, aby mogła być polityką zrównoważonego rozwoju, musi być osadzona na właściwych filozoficznych podstawach. W niniejszym artykule autor bada te podstawy. Bazując na filozofii społecznej francuskiego neotomisty Etienne Gilsona, autor wyróżnia metafizyczne i etyczne podstawy społecznej polityki dla zrównoważonego rozwoju.

Słowa kluczowe: Gilson, polityka, etyka, metafizyka, zrównoważony rozwój, człowiek, osoba, społeczeństwo, państwo.

\section{WSTĘP}

O polityce podobnie jak o nauce można mówić jako o specyficznym typie działania bądź mieć na uwadze tylko jego wytwór. W tym drugim wypadku polityka daje się badać narzędziami nauk historycznych. W niniejszym artykule mniej interesuje nas to ostatnie zagadnienie, a głównie będzie nam zależeć na zbadaniu polityki jako specyficznego typu działania. Chodzi o wskazanie filozoficznych racji polityki ujmowanej czynnościowo. Od lat sześćdziesiątych minionego stulecia $\mathrm{w}$ ekonomii politycznej wyłoniono nowe zagadnienie, które z czasem nazwano problemem zrównoważonego rozwoju ${ }^{2}$. Chodzi w nim przede wszystkim o takie korzystanie $\mathrm{z}$ dóbr tego świata, aby następne pokolenia mogły z nich korzystać w podobnym do naszego stopniu. Jakkolwiek w związku z tym zagadnieniem podnosi się głównie problem ekologii ${ }^{3}$, tak ZR wcale nie sprowadza się do wąsko pojętej ekologii.

W grupie zagadnień ZR należy zamieścić przede wszystkim te, które pozwolą określić warunki rozwoju człowieka jako podmiotu i głównego adresata ZR. Z tego względu problematyka ZR w swym źródłowym znaczeniu ma charakter filozoficzny. Na gruncie filozofii można bowiem wskazać racje polityki, które czynią z niej działanie rozwijające człowieka jako człowieka i to zarówno w naszym, jak i w następnych pokoleniach. W poszukiwaniu tych racji sięgniemy do filozoficznej myśli współczesnego autora francuskiego, reprezentującego neotomizm egzystencjalny, Etienne Gilsona. Wybór ten

\footnotetext{
${ }^{1}$ Ks. dr Andrzej Sołtys, Zakład Nauk Humanistycznych, Wydział Zarządzania, Politechnika Rzeszowska.

${ }^{2} \mathrm{~W}$ dalszej cześci pracy na określenie „zrównoważony rozwój” będzie stosowany skrót ZR.

${ }^{3} \mathrm{Na}$ temat idei zrównoważonego rozwoju zob. J. Berdo, Zrównoważony rozwój, Earth Conservation, Sopot 2006, s. 8-24.
} 
usprawiedliwia systemowość podejścia tego autora do wyłaniających się nowych problemów filozoficzno-społecznych. Wspomniane podejście polega na usytuowaniu nowych problemów w tradycji filozofii klasycznej. W ten sposób przebiega dialog filozofii klasycznej ze współczesnością, w którym systemowo rozwiązuje się nowe problemy filozoficzne. W niniejszym opracowaniu zmierzamy do odpowiedzi na pytanie, jakie filozoficzne racje czynią z polityki narzędzie zrównoważonego rozwoju człowieka zarówno w wymiarze indywidualnym, jak i społecznym.

Mówiąc o polityce, zwykle nadajemy temu słowu co najmniej dwa znaczenia, nie zawsze rozróżniane w potocznej dyskusji. Mówimy o władzy państwowej, o wszelkich działaniach związanych z dążeniem do jej zdobycia, utrzymania oraz wykonywania. Można jednak także rozumieć politykę szerzej, jako sferę wzajemnych oddziaływań między państwem a różnymi zorganizowanymi grupami społecznymi, na którą składa się również działanie legislacyjne i wykonawcze organów władzy w przestrzeni publicznej. $\mathrm{W}$ niniejszym opracowaniu przyjmujemy to ostatnie rozumienie polityki.

\section{METAFIZYCZNE PODSTAWY SPOLECZNEJ POLITYKI DLA} ZRÓWNOWAŻONEGO ROZWOJU

Polityka w swej warstwie teoretycznej jest zależna od metafizyki. I to właśnie ta zależność interesuje Gilsona jako filozofa. W swoich pracach nie zajmował się on polityką zrównoważonego rozwoju. Utrzymywał tylko, że zasadą dobrej polityki jest osoba ludzka. Polityka pozwoli kolejnym pokoleniom partycypować w sposób zrównoważony w gatunku ludzkim wtedy, gdy będzie się kierować w swym działaniu wspomnianą zasadą. Gilson, będąc filozofem, wcale nie rości sobie prawa do rozwiązywania problemów politycznych. Zastrzega nawet, że o problemach prawa, ekonomii czy polityki nie może owocnie dyskutować ktoś, kto by nie był prawnikiem, ekonomistą i politykiem ${ }^{4}$. Uznaje za błędne przekonanie, że praktycznymi problemami polityki winni zajmować się najpierw filozofowie ${ }^{5}$. Z kolei jednak polityk nie może właściwie rozwiązywać swoich szczegółowych problemów bez odwołania się do uprzedzającego w stosunku do polityki metafizycznego poznania. Aby wzmocnić to przekonanie, Gilson powołuje się na autorytet świętego Tomasza z Akwinu, który wskazywał na pewne zasady mające zastosowanie w rozwiązywaniu społecznych i politycznych kwestii, wywodząc je z własnej filozofii i teologii. Francuski tomista w niezmieniony sposób przejął to przekonanie Tomasza z Akwinu.

W myśl tego przekonania metafizyka dostarcza polityce zasad do uporządkowania przestrzeni życia społecznego. Metafizyka wskazuje ostateczne racje zorganizowanego w państwo życia społecznego. Zagubienie czy świadome pominięcie tych racji byłoby równoznaczne z wystawieniem życia społecznego i politycznego na niebezpieczeństwo destrukcji. Dotykamy tu samego fundamentu polityki, którym są metafizyczne przekonania dotyczące relacji między człowiekiem - jednostką ludzką, a społeczeństwem. Między tymi członami zachodzi podobna relacja jak pomiędzy przyczyną i skutkiem. W historii popełniono wiele błędów we właściwym odczytywaniu tej relacji.

Najbardziej powszechnym błędem jest zamiana przyczyny na skutek, przez co w naszym wypadku społeczeństwo traktowano jako rację, z której powodu istnieje człowiek

\footnotetext{
${ }^{4}$ Por. E. Gilson, Elementy filozofii chrześcijańskiej, przeł. T. Górski, Instytut Wydawniczy PAX, Warszawa 1965, s. 244

${ }^{5}$ Por. ibidem, s. 245
} 
- jednostka. Racja w filozofii klasycznej to przyczyna, którą z kolei w omawianym przypadku potraktowano jako przyczynę celowa. Gilson jest przekonany, że złe odczytanie tej relacji uniemożliwia właściwe organizowanie życia politycznego. $\mathrm{Z}$ tego też powodu odrzuca wspomniane rozwiązanie jako błędne i przyjmuje, że człowiek w wymiarze jednostkowym i gatunkowym jest racją społeczeństwa. Wyobraźmy sobie człowieka - powiada Gilson - jako samotne i rozumne zwierzę, które dąży na swój sposób do jakichś konkretnych celów. Ale przecież wyobrażenie takie jest absurdalne, byt rozumny bowiem suponuje jego społeczną naturę. Rozumność, chociaż jest wyznacznikiem natury ludzkiej, jest ona w jednostkowym bycie spotencjalizowana. W rozumność wpisana jest perspektywa własnego rozwoju, który z kolei nie jest możliwy bez życia w społeczeństwie ${ }^{6}$. Zwierzę, nie żyjąc stadnie, nie musi nic tracić ze swej doskonałości, ponieważ ta przysługuje mu już na mocy swej natury. Zwierzęta, nie posiadając rozumu, uczą się od innych tylko posługiwania się cielesnymi narzędziami, ku czemu zresztą popycha je instynkt.

Z człowiekiem rzecz ma się inaczej. Ma on umysł pozwalający na gromadzenie wiedzy, lecz nie może aktualizować potencjalności własnego intelektu bez pomocy innych ludzi. Jednocześnie on sam pomaga aktualizować intelekt innych $w$ takim aspekcie i zakresie, w jakim sam pozostaje $\mathrm{w}$ akcie, a ich intelekt $\mathrm{w}$ tym samym aspekcie $\mathrm{w}$ potencji. Ostatecznie Gilson nie dostrzega w człowieku możliwości zrealizowania jego rozumności poza kontekstem życia społecznego. Konkludując, stwierdza, że nie ma różnicy między powiedzeniem, że człowiek jest zwierzęciem rozumnym, a powiedzeniem, że jest on istotą społeczną ${ }^{7}$. Pierwsze określenie wskazuje na rozumność jako doskonałość natury ludzkiej, drugie dookreśla, że rozumność jest w człowieku spotencjalizowana i tylko w społeczeństwie jednostka ludzka może ją doprowadzić do stanu aktualnego. Społeczeństwo nie jest gromada, stadem, które tworzą zwierzęta. Społeczność ludzka ma ciagłość historyczną, w odróżnieniu od ciagłości czysto biologicznej charakteryzującej gatunki zwierzęce ${ }^{8}$. Jest ona przestrzenią, w której rozumna natura ludzka może osiagnąc swą doskonałość, jest warunkiem jej osiagnięcia. Ale czy każda forma życia społecznego wchodzi w definicję pojęcia człowieka jako zwierzęcia rozumnego?

W definicję pojęcia człowieka jako zwierzęcia rozumnego wchodzi tylko taka forma życia społecznego, która może powodować rozwój człowieka jako osoby, rozwój jego rozumności. $Z$ kolei polityka polega na organizowaniu społeczeństwa w taki sposób, aby wskazany rozwój mógł się dokonywać i pod tym warunkiem można ją nazywać społeczną polityką ZR. Nie uwzględniając natomiast swych metafizycznych racji, polityka nie może być dobra, jej racją (celem) bowiem nie jest wówczas metafizyczna prawda o człowieku i społeczeństwie. Dopiero w kontekście metafizyki polityka jest nie tylko sztuką ${ }^{9}$, ale także w pierwszym i właściwym znaczeniu jest etyką społeczną, na co wskazywał już Arystoteles ${ }^{10}$.

\footnotetext{
${ }^{6}$ Por. ibidem

${ }^{7}$ Por. ibidem, s. 246.

${ }^{8}$ Por. ibidem.

${ }^{9}$ Politykę pojmował w taki sposób Niccolo Machiavelli. Zob. N. Machiavelli, Ksiażę, przeł. Cz. Nanke,

Wydawnictwo „Antyk”, Kęty 2005.

${ }^{10}$ Zob. Arystoteles, Polityka, przel. L. Piotrowicz, PWN, Warszawa 2004.
} 


\section{ETYCZNE PODSTAWY SPOLECZNEJ POLITYKI DLA ZRÓWNOWAŻONEGO ROZWOJU}

W filozofii klasycznej polityka jest etyką społeczną. Gilson, pozostając w tym nurcie filozofowania, wyprowadza normy politycznego działania właśnie z metafizyki człowieka i społeczeństwa. Podobnie jak w każdym bycie stworzonym normy są tam zapisane w postaci celowych struktur. Bóg stworzył jednakowoż człowieka, co społeczeństwo i wpisał w nie cel, który te realizują. Akt stworzenia wszystkiego i skierowania na cel Gilson nazywa prawem Boskim. „Prawo Boskie to sam Bóg jako stwórca natur, takich, jakie są oraz działają zgodnie z właściwymi sobie istotami"11. Prawo Boskie jest dopiero źródłem każdego innego prawa, a przede wszystkim prawa natury. „Prawo naturalne jest szczególnym przypadkiem prawa Boskiego"12. Polega na uczestniczeniu istot rozumnych (ludzi) w odwiecznym prawie Bożym. Jest rozpoznawane przez naturalne światło rozumu ludzkiego przy zachowaniu wolnej woli człowieka, który realizuje je w swym życiu przez dokononywanie wyborów ${ }^{13}$. $\mathrm{Z}$ kolei prawo naturalne jest normatywnym punktem odniesienia dla prawa stanowionego ${ }^{14}$. Opisana konstrukcja prawno-etyczna kieruje poszczególne byty jednostkowe ku wyznaczonemu przez Boga celowi, a jest nim upodobnienie się do Boga, który jest samym istnieniem.

Chodzi o upodobnienie się do Boga przez partycypację w tym, w czym jest Bóg sam w sobie. Spełnia się to w działaniu odpowiednim do stworzonych natur i na miare tych natur. W wypadku człowieka upodobnienie takie dokonuje się przez osobowe działanie, dla którego miarą jest zaktualizowana osoba ludzka. Jest to miara działania zarówno jednostki, jak i społeczeństwa (państwa) ${ }^{15}$. Osiagnnięcie tej miary nie jest możliwe w jednostkowym działaniu osoby ludzkiej, lecz staje się to dopiero możliwe dzięki zaangażowaniu polityki państwa. Osiągany dzięki zaangażowaniu państwa wymiar dobra zwykło się nazywać ,dobrem wspólnym”.

W najstarszych klasycznych dziełach filozoficznych problematyka dobra wspólnego występuje implicite w kontekście rozważań o polityce jako społecznym ludzkim działaniu $^{16}$. Arystoteles zauważył, że człowiek nie jest zdolny do życia w izolacji. Swoją tożsamość określa poprzez odniesienie do innych ludzi. Przejawia się to choćby w tym, że sama natura podzieliła ludzi na mężczyzn i kobiety, którzy łączą się ze sobą, tworząc rodzinę, chociaż najmniejszą, to jednak podstawową formę życia społecznego ${ }^{17}$. Od tej wspólnoty zależy zarówno powstanie ludzkiego życia, jak i jego rozwój.

W średniowieczu explicite problem dobra wspólnego postawił święty Tomasz z Akwinu. Pojęcie, jakie wypracował, stało się przedmiotem odniesienia niemalże

\footnotetext{
${ }^{11}$ E. Gilson, op. cit., s. 246.

12 Ibidem.

${ }^{13}$ Zob. J. Majka, Filozofia społeczna, Wydawnictwo Wrocławskiej Księgarni Archidiecezjalnej, Wrocław 1982 ,

s. 207-210. Więcej na temat prawa naturalnego zob. J. Hervada, Prawo naturalne, thum. A. Dorabialska,

Wydawnictwo „Petrus”, Kraków 2011.

${ }^{14}$ Por. Jan Paweł II, Evangelium vitae, Pallottinum, Poznań 1995, s. 70.

${ }^{15}$ Inaczej ma się rzecz w liberalnej koncepcji polityki, wedle której istotą polityki jest sama polityka z wolnością jako jej nadrzędną wartością. Por. P. Śpiewak, W stronę wspólnego dobra, Fundacja Aletheia, Warszawa 1998, s. 298.

${ }^{16}$ Zob. Platon, Państwo, przeł. W. Witwicki, Wydawnictwo „Antyk”, Kęty 1997; Arystoteles, Etyka nikomachejska, przekł., wstępy i komentarze D. Gromska, L. Regner, W. Wróblewski, wyd. 3, PWN, Warszawa 2002

${ }^{17}$ Zob. Arystoteles, Polityka, I, 1 .
} 
wszystkich dociekań dotyczących tego zagadnienia $w$ następnych stuleciach ${ }^{18}$. Współcześnie, mimo wielu opracowań, nie ma takiej koncepcji dobra wspólnego, która nie byłaby kwestionowana. „Rozpoznanie dobra wspólnego jest jedną z najtrudniejszych do wyjaśnienia koncepcji w dziejach politycznych człowieka"19. A jednak z dobra wspólnego czyni się kryterium etycznej oceny działania państwa w tych koncepcjach polityki, w których płaszczyzny polityczna i etyczna wzajemnie się przenikają i dopełniaja.

Gilson rozwija Tomaszowe rozumienie dobra wspólnego i jego koncepcję polityki, jako działania na jego rzecz. Zgodnie z myślą Gilsona możemy powiedzieć, że wskazane działanie to meritum społecznej polityki ZR. Jednakże dobro wspólne jest wtedy centralną kategorią takiej polityki, gdy jest urobione na podstawie pełnego poznania natury ludzkiej. A do pojęcia dobra wspólnego dochodzi się poprzez badanie natury ludzkiej od strony jej potrzeb. Chodzi o takie potrzeby, które są specyficzne dla człowieka jako człowieka, a których ten w jednostkowym działaniu nie jest w stanie zaspokoić i osiagnąć celów wynikających ze spotencjalizowanej natury. Dobro wspólne jawi się jako cel wpisany w społeczną naturę człowieka i do niego polityka ze swej istoty powinna zmierzać. Społeczna natura człowieka nie może się rozwinąć, to jest osiągnąć właściwego jej celu - dobra bez udziału społeczności, w tym społeczności państwa.

Dobro wspólne jest celem dążenia i działania współpracujących ze sobą różnych podmiotów społecznych. Coraz to większe wspólnoty, aż do wspólnoty państwa umożliwiają i wspomagają osiaganie przez człowieka dobra, które przy współudziale wspólnot mniejszych nie mogłoby stać się udziałem jednostek. To w społeczności i dzięki niej człowiek-jednostka dochodzi do czegoś, czego uprzednio nie miał. Miarą spełniania się człowieka jako osoby jest takie dobro, na którego uzyskaniu nikt nie traci, przeciwnie - wszyscy zyskuja, gdyż społeczność staje się doskonalszą doskonałością poszczególnych jej członków ${ }^{20}$. I to zdaje się być istotą społecznej polityki ZR. Z tego, co powiedziano, wynika, że dobro wspólne czerpie swą treść $\mathrm{z}$ badania natury człowieka w aspekcie jednostkowym i społecznym. Natomiast przyjęcie niewłaściwej wizji człowieka i społeczeństwa pociąga niewłaściwą koncepcję dobra wspólnego i z tego powodu nie może ono być już zasadą polityki ZR ${ }^{21}$.

Dobrem wspólnym jest ostatecznie Bóg. Gilson wykazuje to w następującym rozumowaniu. Otóż przedmiotem ludzkiego pożądania, czyli woli, jest dobro w ogólności. Przemawia za tym to, że wybory konkretnych dóbr nie znoszą samego pożądania, a zatem dobro ogólnie ,zawiera” dobro samo w sobie, mianowicie Boga ${ }^{22}$. W filozofii społecznej Gilsona dobro wspólne implikuje etyczne normy działania w polityce. W konsekwencji płaszczyzny polityczna i etyczna są ze sobą zintegrowane, w przeciwieństwie do

\footnotetext{
${ }^{18}$ W swoich dziełach święty Tomasz z Akwinu użył terminu „dobro wspólne” aż 343 razy. Szczegółową analizę używania tego terminu przez świętego Tomasza z Akwinu przeprowadził A.P. Verpaalen, Der Begriff des Gemeinwohls bei Thomas von Aquin. Ein Beitrag zum Problem des Personalismus, Heidelberg 1964.

${ }^{19}$ M. Novak, Wolne osoby i dobro wspólne, przeł. G. Łuczkiewicz, Znak, Kraków 1998, s. 232.

${ }^{20}$ „I tylko w takiej koncepcji dobra wspólnego, które jest wspólnym celem ludzkiego działania osobowego (każdego człowieka), można realistycznie stwierdzić, że wzrost dobra poszczególnej osoby jest zarazem wzrostem dobra całego społeczeństwa. Doskonalenie się bowiem osobowe nie dokonuje się niczyim kosztem, a służy wszystkim”. M.A. Krąpiec, O ludzka politykę, Tolek, Katowice 1995, s. 117.

${ }^{21}$ Zob. Z.J. Zdybicka, Jan Pawet II filozof i mistyk, Polskie Towarzystwo Tomasza z Akwinu, Lublin 2009, s. $48-49$.

${ }^{22}$ Por. E. Gilson, op. cit., s. 234-235.
} 
współczesnej myśli liberalnej, która je rozrywa i traktuje jako autonomiczne ${ }^{23}$. Dobro wspólne jest u niego tożsame $\mathrm{z}$ dobrem jednostki jako osoby. W konsekwencji nie ma różnicy między kryteriami oceny działania jednostki i państwa, nie ma odrębnej etyki dla jednostki i państwa. W obu przypadkach etycznej oceny działania dokonuje się w oparciu o realizację wskazanego dobra we właściwych dla jednostki i społeczeństwa (państwa) aspektach.

Gilson bada także sposób, w jaki poszczególne byty jednostkowe osiagają dobro wspólne. Dostrzega w niektórych aspektach podobieństwo rozwoju społecznej natury człowieka do zmiany i rozwoju bytów jednostkowych zajmujących niższą pozycję w hierarchii bytowej. Niektóre trudniejsze aspekty tego rozwoju mogą być wyjaśnione przez analogię rozwoju bytów zorganizowanych niżej niż człowiek. Pomiędzy naturą świata i naturą społeczeństwa można dostrzec pewne podobieństwo. $Z$ tego też względu świat $i$ społeczeństwo można uczynić analogicznymi członami. Podobieństwo takie zachodzi pomiędzy niektórymi ich własnościami, a także za pomocą odniesienia do tego samego analogatu głównego, którym jest Prawodawca, jedyne źródło porządku. Co się tyczy podobnych własności, to zarówno natura świata, jak i natura społeczeństwa są hierarchiczne. Zarówno świat, jak i społeczeństwo przejawiają wielość form. Hierarchiczność to z jednej strony nierówność, z drugiej porządek tworzony przez prawo. Prawo jednakowo wnosi porządek do zróżnicowanych form w świecie i społeczeństwie.

Nierówność jest zasadą działania jednych bytów na drugie. Gilson pisze: „sama nierówność postanowiona przez mądrość Boską w rzeczach stworzonych wymaga (exgit), by jedne stworzenie działało na inne" ${ }^{24}$. A jeszcze dokładniej, by doskonalsze stworzenia działały na mniej doskonałe. Doskonałość jest aktem, który działa na odpowiadający jej aspekt bytu będący w potencji. Dzieje się tak zarówno w odniesieniu do struktury wewnątrzbytowej, jak i struktur międzybytowych. Każdy element ontycznej struktury bytu jest utworzony ze struktury bardziej podstawowej, a mianowicie z aktu i możności. Akt realizuje $\mathrm{w}$ nim odpowiadający mu aspekt potencjalny, przez co byt nieustannie podlega zmianie. Ale byt jednostkowy jest też spotencjalizowany $w$ aspekcie całościowym, gdyż jako pochodny nie istnieje na mocy własnej istoty, to znaczy, takiej potencjalności nie może zrealizować żaden element aktualny tegoż bytu, ani też wszystkie momenty aktualne współdziałające w nim jednocześnie.

Zarysowaną odmianę potencjalności mogą zaktualizować byty zewnętrzne w stosunku do nich. Jednak tylko ten byt może aktualizować całościowy potencjalny aspekt bytu innego, o ile sam jest w tym aspekcie aktem. W świetle teorii aktu i możności, wszystkie byty pochodne są ukonstytuowane $\mathrm{z}$ aktu i możności. Wyjaśnia ona zagadnienie hierarchii bytów i z niej wynikającego oddziaływania jednych bytów na inne. W gruncie rzeczy jest to aspekt analogicznego sposobu bytowania rzeczy. Aktualizujące oddziaływanie jednych bytów na inne, bytów doskonalszych na mniej doskonałe, jest przejawem mądrości Stwórcy, która jako odczytana stanowi lex aeterna. Wedle tego prawa niższe byty stają się podobne do wyższych pod wpływem przyczynowego działania na nie tych ostatnich. A zatem byty niższe są skierowane w sposób naturalny do wyższych jako swoich celów.

\footnotetext{
${ }^{23}$ Por. K. Wasilewski, Dobro wspólne w myśli Arystotelesa, [w:] Dobro wspólne, red. D. Porbucka, Kraków 2010, s. 131

${ }^{24}$ E. Gilson, op. cit., s. 247
} 
Natomiast wszystkie byty ujęte kolektywnie kierują się ku temu, który jest Pierwszą Przyczyną świata i ostatecznym jego celem ${ }^{25}$.

Analogicznie do świata fizycznego rozwija się społeczeństwo. Jest ono utworzone z wielości nierównych form, które tworzą hierarchię. Formy bardziej doskonałe wpływaja na mniej doskonałe dla osiagania przez te ostatnie dobra wspólnego. Podobnie zreszta jak w innych dziedzinach aktywności społecznej czy zawodowej, w której plan wszystkiego, co ma być zrobione wypływa od głównego rzemieślnika do współpracujących z nim niższych rzemieślników. W najszerszej wspólnocie takie uporządkowane oddziaływanie jednych form na inne nazywa się polityką. W niej niżsi rządzący wprowadzają plan rządzenia pochodzący od naczelnego rządcy. Rządzenie polega na tworzeniu prawa $z$ moca zobowiązującą do jego przestrzegania przez wszystkich obywateli. Ale nie znaczy to, że ci, którzy tworzą w państwie prawo, czyli mają w nim najwyższą władzę, są absolutnymi suwerenami. Otóż ci nie mogą zmieniać prawa wiecznego, które jest planem rządów istniejącym w Głównym Rządcy. Natomiast wszelkie prawo stanowione przez ustawodawcę $\mathrm{w}$ państwie powinno być tylko przedłużeniem lex aeterna $\mathrm{i}$ jest to konieczny warunek do tego, aby rząd faktycznie mógł doskonalić społecznie zhierarchizowane formy ${ }^{26}$. Polityka społeczna wtedy jest polityką ZR, gdy racja tworzonego przez rządy prawa jest dobro wspólne obywateli państwa.

Rządy w sprawowaniu władzy posługują się prawem. Prawo (ius) domaga się tego, co sprawiedliwe (iustum). Sprawiedliwość natomiast (iustitia) jest postępowaniem sprawiedliwym we wszystkich okolicznościach życia społecznego ${ }^{27}$. W swojej filozofii społecznej Gilson poświęca wiele miejsca zagadnieniu sprawiedliwości. W jego przekonaniu to ona stanowi fundament życia społecznego. Skoro Bóg jest najwyższym prawodawca, to rządy tworzące prawa są tylko „współpracownikami” Boga, o ile stanowione przez nie prawo nie sprzeciwia się lex aeterna. Prawo stanowione jest wtedy sprawiedliwe, gdy wypływa z prawa wiecznego. Jeśli natomiast rządzący stanowią prawo w oderwaniu od lex aeterna, a tym bardziej w opozycji do niego, tworzą coś, co w istocie prawem nie jest ${ }^{28}$. W takich okolicznościach podlegający władzy obywatele nie są zobowiązani do respektowania przepisów wydawanych przez państwo, a będąc im posłuszni, nie są posłuszni prawu, lecz tylko niesprawiedliwym rządom.

Sprawiedliwość zasadza się na stosunkach równościowych. Gilson mówi o naturalnej równości rzeczy ${ }^{29}$. Podobne stosunki zachodzą między jednostkami w państwie czy grupami społecznymi. Można je zilustrować wymianą banknotu na monety. Pomiędzy banknotem a pewną sumą drobnych pieniędzy zachodzi stosunek równości i ten stosunek równości nie powstaje w wyniku umowy, lecz jest czymś naturalnym. Dopiero na nim zasadza się stosunek prawny, którym jest zrównoważenie w wymianie banknotu na drobne pieniądze. Zrównoważenie z jednej strony polega na odczytaniu przez podmiot, względnie podmioty dokonujące wymiany, stosunku równości między członami (banknotem i bilonem), z drugiej na zamianie jednego członu na drugi. W taki sposób przechodzi się od równego sposobu bytowania do sprawiedliwego, a więc zgodnego z

\footnotetext{
${ }^{25}$ Por. Św. Tomasz z Akwinu, Summa contra gentiles, III, c. 17-18, przeł. Z. Włodek, W. Zega, W drodze, Poznań 2009.

${ }^{26}$ Por. idem, Summa theologica, I-II, q. 93, a. 3, przeł., w objaśnienia i skorowidze zaopatrzył Pius Bełch, Veritas, London 1986.

${ }^{27}$ Por. E. Gilson, Tomizm, przeł. J. Rybałt, PAX, Warszawa 1998, s. 350.

${ }^{28}$ Por. idem, Elementy filozofii chrześcijańskiej, s. 249.

${ }^{29}$ Por. idem, Tomizm, s. 350.
} 
prawem działania. Ale nie tylko stosunki równościowe pomiędzy rzeczami są źródłem prawa w państwie. Są też nimi te, które zachodzą pomiędzy rzeczami a człowiekiem, jak choćby wtedy, gdy praca człowieka ma swój pieniężny ekwiwalent. Zachodzą one także pomiędzy człowiekiem jako takim a sposobem jego traktowania. To, kim, czym człowiek jest, ma swój ekwiwalent w odpowiednim wobec niego działaniu. Chodzi nie tylko o działanie jednostki w stosunku do innej jednostki. W polityce rzecz idzie o działanie państwa ze względu na wszystkie jednostki. Takim ekwiwalentnym działaniem państwa jest w tym wypadku działanie ze względu na odpowiednio rozumiane dobro wspólne. Wówczas działanie państwa odpowiada dobru wspólnemu, będącemu dobrem każdej jednostki. Dopiero takie działanie państwa można nazwać społeczną polityką ZR.

Sprawiedliwość, na której zasadza się porządek życia społecznego, nie jest jednorodna. Gilson za świętym Tomaszem $\mathrm{z}$ Akwinu rozróżnia sprawiedliwość szczegółową i sprawiedliwość legalną ${ }^{30}$. Ta ostatnia określa prawe postępowanie poszczególnych jednostek $\mathrm{w}$ stosunku do zbiorowości (państwa). Jest ona sprawiedliwością określoną przez ustawy, które zalecają każdemu takie postępowanie, jakiego wymaga wspólne dobro państwa. Natomiast sprawiedliwość szczegółowa porządkuje całościowe odnoszenie się jednego człowieka wobec drugiego. I to właśnie w zakres tej ostatniej odmiany sprawiedliwości wchodzi już zauważona przez Arystotelesa sprawiedliwość zamienna, regulująca stosunki między prywatnymi osobami (ilustrują ją przywoływane przykłady) oraz sprawiedliwość rozdzielcza ${ }^{31}$. Z kolei sprawiedliwość rozdzielcza reguluje stosunki pomiędzy całością (państwem) a obywatelem. Polega ona na przydzielaniu pojedynczej osobie przypadającej na nią część dóbr stanowiących wspólną własność zbiorowości (państwa). Dopiero ta ostatnia odmiana sprawiedliwości jest zasadą w tworzeniu prawa przez państwo. Podsumowując, powiemy, że etyczną racją społecznej polityki ZR jest właściwie rozumiane dobro wspólne. Polityka społeczna państwa jest wtedy polityką ZR, gdy ma je na uwadze jako własny cel działania. Z jednej strony efektywnie pomnaża takie dobro, $\mathrm{z}$ drugiej sprawiedliwie je rozdziela pomiędzy każdego, kto ma do niego prawo $^{32}$.

\section{ZAKOŃCZENIE}

O polityce ZR można mówić wtedy, gdy ta w sposób zintegrowany troszczy się w państwie o społeczeństwo, środowisko i ekonomię. Rozwój jest zrównoważony, gdy polityka państwa w odniesieniu do wskazanych obszarów jest znośna, sprawiedliwa i wykonalna. Niniejsza praca stanowi próbę aspektywnego ujęcia polityki ZR na gruncie tomizmu egzystencjalnego Gilsona. Ukazano w niej metafizyczne i etyczne racje społecznej polityki ZR. Racją metafizyczną jest teleologiczna struktura bytu ludzkiego w wymiarze indywidualnym i wspólnotowym. Człowiek - osoba ma rację-cel w sobie i jest to ta sama racja, dla której istnieje on sam, a także państwo. Społeczna polityka ZR polega natomiast na wprzęgnięciu działania państwa w realizację wspomnianego celu.

Społeczna polityka jest wówczas polityką ZR, gdy na podstawie tej racji organizuje się życie społeczne i państwowe. W polityce ZR chodzi o tworzenie warunków rozwoju każdej osoby. Spełnienie się człowieka jako osoby jest dobrem wspólnym i etyczną racją

\footnotetext{
${ }^{30}$ Por. Św. Tomasz z Akwinu, Summa theologica, II-II, q. 58, a. 7, resp., przełożył i w objaśnienia zaopatrzył F.W. Bednarski, Veritas, London 1966.

${ }^{31}$ Por. Arystoteles, Etyka nikomachejska, nr 927-937.

${ }^{32}$ Por. Św. Tomasz z Akwinu, Summa theologica, II-II, q. 58, a. 2, resp. i 4, resp.
} 
polityki. Działanie państwa ze względu na dobro wspólne to najbardziej podstawowa norma polityki jako etyki społecznej. Działanie państwa ze względu na dobro wspólne jest w praktyce stosowaniem zasady sprawiedliwości, bez której nie sposób właściwie zorganizować społeczeństwo.

\section{LITERATURA}

[1] Arystoteles, Etyka nikomachejska, przekł., wstępy i komentarze D. Gromska, L. Regner, W. Wróblewski, wyd. 3, PWN, Warszawa 2002.

[2] Arystoteles, Polityka, przeł. L. Piotrowicz, PWN, Warszawa 2004.

[3] Berdo J., Zrównoważony rozwój, Earth Conservation, Sopot 2006.

[4] Gilson E., Elementy filozofii chrześcijańskiej, przeł. T. Górski, Instytut Wydawniczy PAX, Warszawa 1965.

[5] Gilson E., Tomizm, przeł. J. Rybałt, PAX, Warszawa 1998.

[6] Hervada J., Prawo naturalne, tłum. A. Dorabialska, Wydawnictwo „Petrus”, Kraków 2011.

[7] Jan Paweł II, Evangelium vitae, Pallottinum, Poznań 1995.

[8] Krąpiec M.A., O ludzka politykę, Tolek, Katowice 1995.

[9] Machiavelli N., Ksiązę, przeł. Cz. Nanke, Wydawnictwo „Antyk”, Kęty 2005.

[10] Majka J., Filozofia społeczna, Wydawnictwo Wrocławskiej Księgarni Archidiecezjalnej, Wrocław 1982.

[11] Novak M., Wolne osoby i dobro wspólne, przeł. G. Łuczkiewicz, Znak, Kraków 1998.

[12] Platon, Państwo, przeł. W. Witwicki, Wydawnictwo „Antyk”, Kęty 1997.

[13] Śpiewak P., W stronę wspólnego dobra, Fundacja Aletheia, Warszawa 1998.

[14] Św. Tomasz z Akwinu, Summa contra gentiles, III, c. 17-18, przeł. Z. Włodek, W. Zega, W drodze, Poznań 2009.

[15] Św. Tomasz z Akwinu, Summa theologica, II-II, q. 58, a. 7, resp., przełożył i w objaśnienia zaopatrzył F.W. Bednarski, Veritas, London 1966.

[16] Verpaalen A.P., Der Begriff des Gemeinwohls bei Thomas von Aquin. Ein Beitrag zum Problem des Personalismus, Heidelberg 1964.

[17] Wasilewski K., Dobro wspólne w myśli Arystotelesa, [w:] Dobro wspólne, red. D. Porbucka, Kraków 2010.

[18]Zdybicka Z.J., Jan Pawet II filozof i mistyk, Polskie Towarzystwo Tomasza z Akwinu, Lublin 2009.

\section{PHILOSOPHICAL BASES OF SOCIAL POLICY FOR SUSTAINABLE DEVELOPMENT}

The modern political economy has developed the doctrine of sustainable development. The scope of this doctrine includes the environment, economy and society. In the literature on this subject more attention is paid to the environment and the economy, while the issue of social policy goes by the wayside. The author of the present article, inspired by the E. Gilson's thought takes the position that the doctrine of sustainable development cannot be narrowed only to issues of economic policy. Since man is the subject and the recipient of sustainable development, the main issue in the social doctrine should be the policy of the State. The policy of the State, however, in order to be a sustainable development policy must be set at the appropriate philosophical basis. In this article the 
author examines these bases. Based on the E. Gilson's social philosophy the author distinguishes metaphysical and ethical foundations of social policy for sustainable development.

Keywords: Gilson, politics, ethics, metaphysics, sustainable development, human, individual, society, state.

DOI:10.7862/rz.2012.einh.7 